increased synthesis of very low density lipoproteins by the liver after partial hepatectomy.

This work was supported by the Swedish Medical Research council (Project No. B68-13 X-727-03). The skilful technical assistance of Miss B. OLIN is gratefully acknowledged.

Department of Physiological Chemistry,

GÖRAN FEX

University of Umeà, $S$ gor87 Umeả (Sweden)

ThOMAS OLIVECRONA

I R. O. Recknagel, B. Lombard and M. C. Schotz, Proc. Soc. Exptl. Biol. Med., ro 4 (1960) 608.

2 B. Lombardi and R. O. Recknagel, Am. J. Pathol., 40 (1962) $57 \mathrm{I}$.

3 D. S. Robinson And A. Seakins, Biochim. Biophys. Acta, 62 (ro62) I63.

4 S. Ludewig, G. R. Minor and J. C. Hortenstine, Proc. Soc. Expll. Biol. Med., 42 (1939) 158.

5 R. D. Harkness, $J$. Physiol. London, II7 (1952) 267.

6 A. M. SCANU, Advan. Lipid Res., 3 (1965) 63.

7 M. Friedman and S. O. Byers, $A m$. $J$. Physiol, roo (I957) 439.

8 G. M. Hrgains and R. M. Anderson, Arch. Pathol., i 2 (I93I) 186.

9 J. Folch, M. Lees and G. H. Sloane Stanlex, J. Biol. Chem., 226 (1957) 497.

Io T. Olivecrona, Acta, Physiol. Scand., 54 (1962) 295.

i I P. Belfrage and A. Lundgvist, to be published.

12 E. VAN Handel and D. B. Zlluversmit, J. Lab. Clin. Med., 50 (1957) I52.

13 P. S. Chen, T. Y. Toribara And H. Warner, Anal. Chem., 28 (1956) I756.

I4 G. Fex and T. Olivecrona, Biochim. Biophys. Acta, I 52 (I968) 237.

I5 S. OTWAY AND D. S. RoBtnson, J. Physiol. London, Igo (1967) $32 \mathrm{r}$.

i6 P. J. Nestel and D. Steinberg, J. Lipid Res., 4 (1963) 46 I.

I 7 R. J. Stenger and D. B. Confer, Exptl. Mol. Pathol., 5 (I966) 455.

I 8 N. L. TrotTER, J. Cell Biol, 2 I (I964) 233.

ig A. L. Jones, N. B. Ruderman and M. G. Herrera, J. Lipid Res., 8 (1967) 429

20 R. L. Hamilton, D. M. Regen, M. E. Gray and V. S. Le Quire, Lab. Invest., i6 (1967) 305.

Received July 8th, I968

Biochim. Biophys. Acta, $\mathrm{I}_{4}$ (1968) 424-426

BBA 53189

\title{
Phospholipid precursors of prostaglandins
}

Several unesterified prostaglandin derivates are produced by sheep vesicular gland homogenates in vitro $0^{1-3}$. Prolonged synthesis of these derivates $i n$ vivo would tend to deplete the available substrates and draw upon precursors of the free fatty acids since the level of unesterified fatty acids is generally low in tissues. As one possibility, the large reservoir of polyunsaturated acids bound in ester form might undergo oxidative cyclization to prostaglandin either prior to or following hydrolysis. To investigate whether the cyclization reaction could occur directly with the phospho-

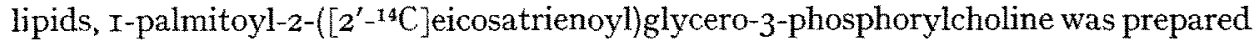
and incubated with enzyme preparations from sheep vesicular glands. Although unesterified prostaglandins were formed from the phospholipid, no appreciable amount of radioactive prostaglandin was found esterified to phospholipid. These results sug- 
gest that prostaglandin may be most rapidly formed if hydrolysis precedes the cyclizing reaction.

The fatty acids available in the form of phospholipids in sheep vesicular gland were determined by gas chromatography. Phosphatides extracted from the tissue were eluted separately from small columns of silicic acid and converted to methyl esters by methanolysis in the presence of sodium methoxide. Gas-liquid chromatography on EGSS-X gave values of equivalent chain lengths for the esters that were in close agreement with those obtained with DEGS (ref. 4). Tentative assignments were made after comparing equivalent chain length values of 9 saturated and polyunsaturated reference esters in the manner described by HOFSTETTER AND HoLmAN ${ }^{4}$. The compositions obtained in this way are presented in Table I.

TABLE I

FATTY ACID COMPOSITION OF VESICULAR GLAND PHOSPHOLIPIDS

Figures represent male $\%$.

\begin{tabular}{lcc}
\hline Fatty acid & \multicolumn{2}{c}{ Phosphoglyceride fraction } \\
\cline { 2 - 3 } & Choline & Ethanolamine \\
\hline 16:0 & 26.3 & 12.6 \\
$18: 0$ & 14.7 & 17.4 \\
$18: 1(n-9)$ & $25 \cdot 3$ & 21.6 \\
$18: 2(n-6)$ & 5.6 & 5.9 \\
$20: 1(n-9)+18: 3(n-3)$ & 0.8 & 0.9 \\
$20: 2(n-9)+18: 4(n-3)$ & 1.8 & 3.5 \\
$20: 3(n-6)$ & 17.5 & 21.8 \\
$20: 4(n-6)$ & 1.5 & 3.1 \\
$20: 5(n-3)$ & 1.9 & 2.4 \\
$22: 3(n-9)+(n-6)$ & 1.7 & $3 \cdot 5$ \\
$22: 4(n-6)$ & 0.2 & 0.3 \\
$22: 5(n-6)$ & 0 & 0.1 \\
$22: 5(n-3)$ & 1.4 & 2.9 \\
$22: 6(n-3)$ & 1.4 & 2.5
\end{tabular}

The high level of $20: 3$ and the low level of $20: 4$ are in marked contrast to the high level of 20:4 found in liver lecithins ${ }^{5}$. If phospholipid acids are the natural precursors of the prostaglandins in vivo, prostaglandin $\mathrm{E}_{\mathbf{1}}$ would be expected to be produced in greater abundance since its precursor is 20:3. A similar consideration ${ }^{6}$ was applied to the prevalence in renal medulla of prostaglandin $\mathrm{E}_{2}$ which is derived from the abundant acid, 20:4. The ligh relative amount of $20: 3$ in vesicular gland phosphatides was also reflected in a similar composition of the unesterified acids of the tissue. Non-esterified 20:3 was, however, found in amounts (about ro nmoles/g) that were only $0.2-1.0 \%$ of that in phospholipids. We observed that the small amount of unesterified $20: 3$ in homogenates decreased under incubation conditions that led to prostaglandin $\mathrm{E}_{1}$ synthesis.

Radioactive eicosatrienoate was synthesized as previously described ${ }^{3,7}$.

The CoA thiol ester was prepared from the acid chloride by a modification ${ }^{8}$ of the procedure described by SEUBERT ${ }^{9}$. I-Palmitoyl-2 ([2' $\left.{ }^{14} \mathrm{C}\right]$ eicosatricnoyl)-glycero3-phosphorylcholine was then synthesized from I-palmitoylglycero-3-phosphorylcholine ${ }^{10}$ and $\left[2-{ }^{14} \mathrm{C}\right]$ eicosatrienoyl-CoA by the action of microsomal acyltransferase preparation from pig liver. The radioactive product which was purified by silicic acid chromatography contained $2 \cdot 10^{5}$ counts/min per $\mu$ mole. 
The radioactive lecithin was shown to be homogeneous by thin-layer chromatography on silica gel $\mathrm{H}$ plates using chloroform-methanol-water $(65: 35: 5$, by vol.). A small amount of the radioactivity $(2-4 \%)$ appeared on the control thin-layer chromatographic plates as free acid even after repeated purifications of the lecithin and is most likely produced when evaporating and applying the washed lipid sample to the plate.

Sheep vesicular glands were homogenized in 3 vol. of phosphate buffer ${ }^{11}$ and centrifuged at $8000 \times g$ for 15 min. The supernatant fraction, which contained microsomes, was used for several incubations. In some cases, this preparation was further centrifuged at $100000 \times g$ for $I$ h to obtain a microsomal fraction which was used both with and without supplemental additions of the $100000 \times g$ supernatant. The radioactive phospholipid ( 6000 counts $/ \mathrm{min})$ was incubated at $37^{\circ}$ for varying periods of time and then all lipids were extracted with chloroform-methanol $(2: I, v / v)$. The total lipid extract was applied to thin-layer plates containing silica gel $G$ and developed with a solvent system modified from that recommended by GRÉEN AND SAMUELSSON ${ }^{12}$. The plate was first developed to $\mathrm{I} 5 \mathrm{~cm}$ with benzenedioxane-acetic acid (80:I8:2, by vol.) and then after drying, to $4 \mathrm{~cm}$ with diethyl ether. The lipids were located by spraying $\mathrm{I} \%$ iodine in methanol over the plate. After the iodine evaporated, the regions were scraped into scintillation vials, suspended in aqueous dioxane ${ }^{13}$ and counted in a scintillation counter.

When the radioactive phospholipid was incubated with the $8000 \times g$ supernatant of a vesicular gland homogenate, unesterified prostaglandin $E_{1}$ was slowly produced. The amount of prostaglandin $\mathrm{E}_{1}$ was increased by adding a I00000 $\times g$ supcrnatant fraction from rat liver or sheep vesicular gland homogenates. The results in Table II show that added supernatant increased the total free acids produced from the precursor lipid. Supernatant alone, which contains no cyclizing activity, led to an increase of radioactivity in only non-esterified 20:3. The radioactive

\section{TABLE II}

THIN-LAYER CHROMATOGRAPHIC SEPARATION OF TOTAL RADIOACTIVE LIPIDS FROM INCUBATION MIXTURE

Enzyme preparations in Expt. A were the $8000 \times g$ supernatant (VG) from sheep vesicular gland and a $100000 \times g$ supernatant (LS) from rat liver. The control incubation was stopped immediately with chloroform-methanol, whereas the other tubes were incubated at $37^{\circ}$ for $75 \min$. Enzyme preparations in Expt. B were microsomes (VGM) prepared from sheep vesicular gland and the I $0000 \times g$ supernatant (LS) from rat liver. The incubations were carried out at $37^{\cup}$ tor $I \mathrm{~h}$. Figures represent counts/min per fraction.

\begin{tabular}{|c|c|c|c|c|c|c|}
\hline Band designation & $\begin{array}{l}\text { Expt. A } \\
\text { Control }\end{array}$ & $V G+L S^{-}$ & $L^{-} S^{-}$ & $\begin{array}{l}\text { Expt. B } \\
\text { Control }\end{array}$ & $\overline{V G} \overline{M+L S}$ & $L \bar{S}$ \\
\hline Solvent front & 170 & 20 & 40 & 60 & 30 & 50 \\
\hline Normal acids & $\begin{array}{l}20 \\
10\end{array}$ & $\begin{array}{r}15^{\circ} \\
5^{\circ}\end{array}$ & $\begin{array}{r}630 \\
10\end{array}$ & $\begin{array}{l}\text { Io } \\
\text { Io }\end{array}$ & $\begin{array}{l}160 \\
140\end{array}$ & $\begin{array}{r}910 \\
0\end{array}$ \\
\hline Hydroxy acids & $\begin{array}{l}0 \\
0\end{array}$ & $\begin{array}{l}90 \\
30\end{array}$ & $\begin{array}{l}20 \\
\mathrm{IO}\end{array}$ & $\begin{array}{l}80 \\
\text { To }\end{array}$ & $\begin{array}{r}260 \\
4\end{array}$ & $\begin{array}{l}\text { Io } \\
\text { Io }\end{array}$ \\
\hline Prostaglandins & $\begin{array}{l}10 \\
20\end{array}$ & $\begin{array}{r}39^{\circ} \\
20\end{array}$ & $\begin{array}{l}20 \\
10\end{array}$ & $\begin{array}{r}5^{\circ} \\
130\end{array}$ & $\begin{array}{l}570 \\
290\end{array}$ & $\begin{array}{l}30 \\
90\end{array}$ \\
\hline $\begin{array}{l}\text { Phospholipids } \\
\text { (Origin) }\end{array}$ & 5140 & 3870 & 4600 & 3900 & $294^{\circ}$ & 3610 \\
\hline
\end{tabular}


phospholipid remaining at the origin of the chromatographic plates was eluted with methanol and hydrolyzed at $37^{\circ}$ for $45 \mathrm{~min}$ with $0.5 \mathrm{M} \mathrm{NaOH}$ in $75 \%$ methanol in water. The saponification mixture was acidified with acetic acid and treated with ether. The extracted acids derived from the phospholipid were chromatographed on silica gel $G$ in benzene-dioxane-acetic acid ( $82: 13: 2$, by vol.). $93 \%$ of the radioactivity $( \pm 3 \%$ ) chromatographed with unreacted $20: 3$ and no other major component was detected. Significantly, the same result was obtained if the radioactive phospholipid was incubated with only buffer, or allowed to react with the vesicular gland preparation for less than $30 \mathrm{sec}$. These results, therefore, suggest that no newly synthesized prostaglandin is esterified to the phospholipid. The radioactive prostaglandins produced in incubation mixtures containing added supernatant fractions seem most probably to have been formed from the liberated 20:3 rather than from the esterified form. Similar results were obtained independently by VoNKEMAN AND VAN DORP ${ }^{14}$.

This work was supported in part by a grant from the National Science Foundation (GB5767) and from the Swedish Medical Research Council (Project r3X-2I7).

Department of Biochemistry, The University of Michigan, W. E. M. LANDS Ann Arbor, Mich. 48104 (U.S.A.)

Department of Medical Chemistry, Royal Veterinary College, Stockholm (Sweden)

i D. A. Van Dorp, R. K. Beerthius, D. H. Nugteren and H. Vonkeman, Biochim. Biophys. Acta, $90(1964) 204$.

2 D. A. Van Dorp, R. K. Beerthius, D. H. Nugteren and H. Vonkeman, Nature, 203 (1964) 839 .

3 S. Bergström, H. Danielsson, D. Klenberg and B. Samuelsson, J. Biol. Chem, 239 (1964) $\mathrm{PC}_{4}$ oo6.

4 H. H. Hofstetter and R. T. Holman, J. Am. Oil Chemists' Soc., 43 (1965) 290.

5 W. E. M. Lands and P. Hart, J. Am. Oil. Chemists' Sac., 43 (I966) 290.

6 E. G. Daniels, J. W. Hinman, B. E. Leach and E. E. Muirhead, Nature, 215 (I967) 298.

7 E. Klenk and H. Mohrhauer, $Z$. Physiol. Chem., 320 (I960) 218.

8 W. E. M. Lands, M. L. Blank, L. J. Nutter and O. S. Privett, Lipids, I (1966) 224.

9 W. Seubert, Biochem. Prepn., 7 (Ig60) 80.

10 A. E. Brandt and W. E. M. Lands, Biochim. Biophys. Acla, 144 (1967) 605.

i I S. Bergström and U. Gloor, Acta Chem. Scand., 9 (I955) 34.

I2 K. Gréen and B. Samuelsson, J. Lipid Res., 5 (1964) I 77.

13 F. SNYDER, Anal. Biochem., 9 (1964) 183.

i 4 H. Vonkeman and D. A. Van Dorp, Biochim. Biophys. Acta, i64 (1968) 430.

Received August I4th, I968 